DOSSIER DE CREACIÓN 


\section{PÍA BARROS}

Es una de las escritoras más activas y renombradas de la literatura chilena actual. Su nombre generalmente se vincula a la literatura feminista y su obra tiene una marcada connotación erótica y social. Entre sus publicaciones se cuentan Miedos transitorios (1985), El tono menor del deseo (1990), Signos bajo la piel (1994), Ropa usada (2000) y Los que sobran (2002). Sus cuentos han aparecido en numerosas antologías de Chile y el extranjero. $\mathrm{Ha}$ publicado una treintena de libros-objeto con material literario ilustrado por destacados artistas gráficos, y tiene a su haber la primera novela chilena publicada en formato digital, Lo que ya nos encontró, editada por Chilelibro.com en 2000.

Dirige el taller Ergo Sum desde 1976. 


\section{Edificio uno, origen}

A pesar de que la tierra crece hacia arriba sobre la tumba de sus ancestros, decidimos pedir su ayuda y fui el emisario designado para golpear su puerta, premunido de overol plástico y mascarilla. No era la idea que teníamos de pueblo originario la que me abrió. Perfectamente maquillada, elegante, no se asombró ante el petitorio. Con un gesto de la mano, asintiendo, me indicó la salida. Encerrado y vigilando tras el visillo de seguridad, la observé dirigirse hacia el 982. Abrió su bolso, tomó un cigarro y lo encendió con elegancia. Después tocó con los nudillos. El tipo abrió en camiseta y calzoncillos y la insultó antes de que ella pudiera hablar: "Saldré todo lo que quiera y métanse su puta cuarentena por...”. Entonces ella expelió el humo con lentitud sobre su rostro, y dijo con voz profunda y pausada: "Yo te maldigo". Dio media vuelta y regresó a su departamento.

Ahora esperamos a que el personal de seguridad venga a retirar el cadáver contaminado caído en la entrada de nuestro edificio.

\section{Edificio uno}

La chica hace señas desde la ventana hasta que consigue la atención de la mujer cabizbaja en el edificio del frente, tercer departamento, octava ventana. La mujer se pone de pie sosteniéndose en el marco.

Desde la otra vereda, la chica saca un parlante y micrófono en mano comienza, sobrecogida, la canción. Las otras ventanas se abren poco a poco para oírla, y llorar junto a ella en cada nota.

La mujer demacrada de la ventana cruza los brazos sobre el pecho en señal de amor. Con las manos, gesticula enviando besos al aire. Luego, se sostiene del marco y sube al borde. En el gesto, abraza a la chica que se abraza a sí misma en reconocimiento. La mujer salta al vacío con los brazos llenos de la imagen de la chica del otro lado de la acerca.

La chica solloza "Adiós, mamá" y los balcones cierran postigos uno a uno.

Mañana habrá más despedidas a lo lejos.

\section{Edificio dos}

La mujer pone muchas almohadas al niño que tose, pero no es suficiente. La puerta es derribada por dos vecinos con overol y mascarillas que la empujan, rebuscan y agarran al infante oculto bajo las almohadas. Uno lo arrastra escaleras abajo y el otro tapia con tablas y clavos el acceso a la mujer que aúlla en su dolor impotente. 
El niño es arrojado a las puertas del edificio, donde yacen, desparramados, viejos, jóvenes, y una que otra criatura congelada en el pavimento.

\section{Edificio tres}

Atento al más mínimo sonido, espía con la oreja pegada a la pared de su departamento. Escucha el celofán del envoltorio y presiente que del otro lado intentan hacer el menor ruido posible. Toma el cuchillo cocinero, el más grande. Sale. De una patada derriba la puerta contigua y sorprende al niño abandonado, moquillento y solo, echándose a la boca los granos crudos de un arroz apolillado.

Esconde el rostro con sus manos para que no lo vea llorar. Toma al niño aterrado en sus brazos, la bolsa de arroz y entra a su departamento. Ambos han saciado la inmediatez de la tripa crujiente. Ahora niño y él, cuchillo en mano, pegan la oreja a la siguiente pared...

\section{Edificio cinco}

No nos gusta el encierro, así es que el Juancho, Nieves, Lucas y yo, que somos del primer piso, nos arrancamos por las ventanas y a susurros, vamos dando vueltas en la noche, entre los autos estacionados que acumulan el polvo de los meses de cuarentena. Nieves roba caramelos y chocolates de los que no han quedado asegurados y nosotros desinflamos ruedas, escribimos obscenidades en los vidrios, hurgamos entre las bolsas de basura. Ahora ya no nos asustamos cuando de las bolsas negras salen dedos de manos o pies fuera de su contenido. El juego es quién los encuentra primero. Lucas va ganando, el Juancho y yo sólo hemos contado 9 vecinos cada uno.

\section{Edificio siete}

Siempre tuve vergüenza de la provincia, suponía que la llevaba como una enchastre de humo sobre la piel. Que nadie notara que mi aire mundano y la actitud desenvuelta no eran capitalinos, así es que callaba mi placer ante el ruido de la ciudad, las bocinas, el tumulto. Ahora aúlla un silencio que raspa la piel en las esquinas. Cuando bajé, con el miedo al contagio mordiendo mis piernas, eché a andar por la ciudad como si me perteneciera. Llevo días vagando, con modales refinados que pierdo a ratos para robar en las vidrieras rotas, algún rastrojo de comida abandonada. Autos de puertas abiertas, silencio campesino sobre el cemento. Tal vez sea la última persona que queda añorando el ruido. 


\section{Edificio once}

Ponemos los muebles en las ventanas y nos atrincheramos temblando mientras la noche llega. Aún sale agua de los grifos y llenamos los vasos de cristal comprados en tres cuotas, observando cómo el juego de living docemesesplazo tapia puertas y ventanas. La abuela se ha quitado los dientes que ya no necesita y reparte entre nosotros la última marraqueta rancia. Hacemos caso omiso de los hongos que asoman en nuestra ración y masticamos lentos, mezclando con sorbos de agua. Los de afuera, sin nada que perder, arrastran el hambre hasta nuestros edificios e imaginan banquetes de condominio, blandiendo palos y palas. A ratos el foco de los helicópteros los amedrenta y retroceden un poco. Los otros, nosotros, encerrados de afuera y de dentro, en el largo latigazo del hambre. 


\section{ROSABETTY MUÑOZ}

Escritora y profesora chilota. Es una de las mujeres poetas del sur más difundidas y sus obras han sido premiadas a nivel nacional e internacional. En el año 2000 fue galardonada con el Premio Pablo Neruda y ganó el Premio Altazor en el año 2013. Entre sus obras destacan Sombras en el Rosselot (2002), Ratada (2005), por la que recibió el Premio Manuel Montt que entrega la Universidad de Chile, y Ligia (2019). Ha sido nominada por la Universidad de Los Lagos al Premio Nacional de Literatura. 


\section{La voz de la casa \\ Ejercicios para vivir el confinamiento}

Lo primero será armar un escapulario por cada habitante. Tendrá una hoja de ruda en el frente y la palabra clave cosida en el revés. Se colgará del cuello con tiras de lana colorada y no se sacará a la vista hasta que termine el año de la peste.

Lo siguiente es volver a las cocinas. Todos, a las fragancias y el hermoso paladar, a la lengua original. Ahí está el niño y su hermana con el volcán de harina, poniendo la levadura, esperando que leude mientras la miran fijamente. Los hermanos no pelean y aprenden a hacer el pan.

Ojalá todas las noches, se pondrá una silla en el centro de la sala y se subirá al niño que dirá un poema. Para acoger este momento con los sentidos aún sin nombre, apagar lámparas y ampolletas. A la luz de una vela, continuar la rueda contando historias uno a uno mientras los sombreados rostros se muestran sólo en fragmentos.

Con un papel de periódico bien arrugado, limpiar el vidrio lo más lentamente posible. Sólo un pedacito y mirar desde allí el afuera. Ampliar el círculo para sorprenderse de a poco. Mirar como si fuéramos un gato, o un anciano, o un niño que aún no sabe nombrar. $\mathrm{O}$ alguien que ya está muerto o uno que volvió de otros mundos.

Tomar un trapo y hacer el ejercicio de limpiar hacia dentro. Repasar las rebeldes convicciones, sacar las costras de lo que se ha aprendido y abrirse a reconocer los magníficos habitantes del espacio interior.

Cerrar los ojos y revivir cuando las madres iban al mercado, no hace tantas vidas; uno volvía de la escuela, tiraba la pita amarrada en el picaporte y ya estaba en el cálido refugio del hogar.

Abrir cajones y pensar en cada prenda, algo. Darle una vida. ¿Por qué me gusta tanto esa blusa? ¿Porque no se notan los senos? Desde la primera vez que iba en la calle y un hombre viejo me dijo algo que no recuerdo, pero tropecé y me puse colorada y me sentí sucia y llegué a mi casa llorando como si hubiese hecho algo malo. Desde entonces todo ha sido cubrir, aplastar, olvidar.

La nieta está parada frente a la ventana, espera al cartero. Hay abuelas que hurgan en sus cajones y han encontrado sobres, flores secas y tarjetas. Abuela y nieta retoman el papel, se han detenido en las letras, en las frases. A veces la carta sólo trae dibujos del rincón que están preparando para sentarse a contar todo lo que les pasa. Buscan palabras para mantener el cuento y seguirlo hilando cuando se junten de nuevo.

Sacar filo a todos los bordes de acero, tener preparadas las hojas para hacer los cortes necesarios. Hay púas también y malas miradas. Hachar, talar, volverse feroz para proteger los claros tan trabajosamente conseguidos. 
Recuperar una fotografía, sentarse en el flojero, mirarla detenidamente, como le exige el tiempo a cada acción nuestra en estos días. Por qué la distancia entre unos y otros, qué hacíamos un rato antes ese día, por qué llevábamos esa ropa, de dónde salió, quién tenía cámara, cómo estaba el día, qué hicimos después. Hay tantas imágenes, que ya no nos dicen nada. Tomar este pedazo de papel, una sola fotografía y dedicarse a ella.

Por ningún motivo olvidar a los muertos. Sentarse con los niños de la casa alrededor de la mesa de la cocina y ponerse a elaborar flores enceradas para cuando se pueda ir otra vez a conversar con los que partieron. Unos cortarán pétalos de papel volantín, otros enderezarán alambre para los tallos; la madre calentará restos de esperma y - si tiene- le agregará velas de colores. Mientras todos trabajan, se irán acordando de los mayores, lo que hacían, cómo eran. Se hablará de ellos hasta que aparezcan y se sienten en el corro con sus cuerpos de aire. Se tomarán las flores desde el alambre y se sumergirán en la cera, se dejarán enfriar y se colocarán en el canasto que se ríe a boca abierta.

Habrás de poner una taza bajo la llave que gotea, junta ese líquido para lavarte la cara. En las bajadas de agua coloca tiestos en desuso, una tetera vieja, un tarro de café. Cuando llueva, acumularás agua para regar tus plantas.

Recuperar el dedal, la aguja y el hilo. Desempolvar la máquina de coser y recordar a la abuela sentada cosiendo blondas en las bolsitas de los porotos para la clase de matemáticas. $\mathrm{O}$ a la madre haciendo bordes de género en la capa de plástico que hacía las veces de impermeable. O la misma madre cosiendo ropa para las muñecas. Acuérdate cómo peleabas con ella por los detalles del vestido para ir a la fiesta.

Mirarse en el espejo más pequeño de la casa, o en el reflejo de un vidrio. Revisar las huellas de las distintas edades que has vivido.

Rebuscar en el canasto de las lanas, hurgar entre los colores, tomar un extremo del primero y tirarlo mientras va apareciendo la escena de una pelea entre los mayores, destejer las palabras hirientes y preguntarse por qué lo olvidamos.

Forrar una caja de zapatos con recortes de género o papel, festonear los bordes, colgar — tal vez- de la tapa, pequeños adornos. Cada uno tendrá la suya. Poner dentro cada día una palabra en la mañana para que marque el día y otra en la noche que resuma su devenir. Fijar un día sagrado para abrir la caja. Se leerán las palabras lento lento, para que vayan encontrando su lugar en el complicado mapa de los días.

El niño más triste puede hacer un bebedero para pájaros con agüita azucarada para que se asomen con su plumaje tornasol y descansen juntos del intenso aletear.

Protegerse como un explorador, con linternas, ropa liviana, guantes y salir a buscar objetos perdidos. La casa ha ido tragándose a lo largo de los años calcetines, tazas, manteles, cuadernos de notas, tenedores ¡cuántos tenedores! Hacer un mapa y repartirse las rutas de búsqueda. 
Prepararse para cuando se pueda salir. Como después de un temporal, hay que ir a la playa y recoger lo que varó. Todos los locos, cochayuyos, piures que se soltaron con las furiosas arremetidas del mar. Recoger todos los restos que nos sirvan para el buen vivir.

El porvenir nuestro está allá atrás. Y bien adentro. 


\section{KEMY OYARZÚN}

Doctora en Filosofía con mención en Literatura de la Universidad de California y fundadora, en 1991, del Centro de Estudios de Género y Cultura en América Latina (Cegecal) de la Facultad de Filosofía y Humanidades en la Universidad de Chile. Ha publicado múltiples ensayos y varios libros sobre la materia. Los dos últimos se titulan Imaginarios críticos de género en la postdictadura y Polifonías del cuerpo en literatura chilena contemporánea. 


\section{A la hora del contagio}

A Guadalupe Santa Crur

I

Cerradas ya estaban las puertas y vaciadas las perchas, sin cobertura de piel ni tiznados telares: solo bocas selladas.

Bajo los cartones miraba, rumas de toallas y frazadas olía.

Plásticos y trozos de lana, cajas, túneles de escombros.

Y hasta carpas. Bolsas plásticas, por lo del contagio.

Adentro nos aprieta el hambre mientras husmea.

Mientras bufa tras la ventana la huella del hambre.

Grito encendido que no calla.

Ladraba la muerte en el silencio de las calles.

Desiertas ya y escombrosas, en Chungará con Santa Julia.

Cuando se la llevaron después, sin la madre de sus huesos.

Entonces husmear cuanto restaba:

Los pañales de la mujer y su colchón, los cubre zapatos.

Todo, para no pisar aquello, porque el hambre hiede

decía, porque el hambre viene y te curva en dos.

Duele para adentro, gritaba, pero nadie oía.

Que estaban todas ya fugadas tras la casa de los huesos, y el sentido inerme del viento.

Cuando ya ni camastro, ni ración.

Que desinfectan para no ver, chillaba a media tos, con el poco aire que quedaba, cuando nos fuimos cavando vísceras como guiñapos, en plena estómaga funeraria.

Tú ya no estás, le dijo, compañera de viajes y de andanzas, Solo bufanda desteñida, apenas camiseta de manchas, derrota del espanto tu sábana invernal.

$\mathrm{Ni}$ del contagio ni del ritual fungido, tampoco del crematorio, sin su barca. 


\section{III}

Entre tanto los que comen se esconden.

Amasan su viático, sus cuentas y sus tarjetas plásticas.

Avivan la higiene a todo cloro y mascarillas.

Y lavan, frotan sus manos incansablemente.

En soledad.

Por eso no veían ni adivinaban sus pasos.

Las suelas no veían. Los troncos no adivinaban.

Eran solo datos sociales, decían, datos que no aparecerían en ninguna parte.

\section{IV}

Pero ella se frota la palma, bebe su mugre por derramar, para no ensuciar, para no fluir ni babear, para no gritar lo que otros callan. Entonces cuenta los grifos y el agua sucia, esa que sale de ella misma, porque los flujos no se compartan.

Porque los cuerpos no se toquen, ni se huelan.

Porque ni se sientan, ni pelos tan siquiera se succionen ya, para qué.

Y se vuelve a lavar. Se refriega hasta sangrar:

a no sentir las zonas rosáceas, inflamadas, amarillas a veces.

$\mathrm{Y}$ verdosos, agitados sus gérmenes todos, se vuelve a lavar, frota con virutilla la grasa adherida a los poros, a sus gruesos labios inferiores.

Mas, ni pan ni cebada. Solo tripas contra tripas.

Que esto es como nacer muerta y privada de calor, porque mil veces preferible morir a caudales, en justas batallas afuera y de sangre goteando, porque soy pueblo ardiente, puebla de rigor.

Contigo es contagio, insistían incólumes, hasta que suspiró toda su fiebre y su escupitajo.

Tú te rozabas en ritmo deleite, acaballada y sudorosa: 
Soy la muerte y nos llevo, decía, a tranco limpio, por las piedras rotas de esta ciudad.

Con los troncos que arraso y la furia que arrastro. Somos la muerte, carajo, sin vacuna ni protección. Sin alcohol gel. Ni desinfectante.

Soy el deseo de tu muerte, el odio de tu hambre, la rabia de todas tus derrotas, de todas tus fatigas la impaciencia, de tu rebeldía en ciernes, la fogata.

El espesor de tus pliegues, de todas tus torturas el horror, de todas las cloacas que tragaste, de todo cuanto escupí en ti, y tapé en ti, y robé de ti, y usurpé y rasgué, y oculté, y aplasté y mentí de ti.

De todo cuanto renegué. De tu estirpe. Que es también la mía.

\section{$\mathrm{V}$}

Por esos días ella se alzó. Incólume, miró de frente:

Y Chilla, sopla, entonces; cruje, grita, se encoge al fin hasta llegar al hueso del habla, sin artefactos ya, ni combustibles y con las tibias llenas de su grasa.

Suciedad incrustada de siglos, se decía, mientras miraba las costras, los tejidos, los pliegues espurios, sin lavazas.

Rabia feroz entonces, a horcajadas de bilis y de esperma.

Bufa de tórax su ira verde. Bufa la vilipendiada.

Y cruje el esternón sin su casco, tibia todavía, la humedad anal, la vagina incrustada, las muelas picaneadas, el "potro", la inmersión.

Entonces, al fin arrasar y el miedo batir:

las medusas todas sueltas como escupitajos, invencibles y gozosas.

Óleos son, de tu cuerpo lleno, flujo, decía para adentro.

Salivilla de goce, mocos espesos y negruzcos.

Olor a almizcles de esos con grosor.

Vana desinfección la de las pieles.

Las paredes mucosas, siempre inestables, plenamente visibles, indivisibles, fluidas y danzantes:

Sones de memorias. Ardientes fuegos de amanecer. 


\section{NAÍN NÓMEZ}

Profesor de Filosofía de la Universidad de Chile, Master of Arts de Carleton University y $\mathrm{PhD}$ en la Universidad de Toronto, Canadá. Ha sido profesor en la Universidad de Chile, en la Universidad Técnica del Estado, en Queen's University de Canadá, en California State University en Long Beach, Estados Unidos, en la Universidad de California en Irvine, Estados Unidos, y en la Université de Poitiers en Francia. Actualmente, es Profesor Titular y Académico de Excelencia en la Universidad de Santiago (Chile). Entre sus publicaciones poéticas se cuentan Historias del reino vigilado/ Stories of a Guarded Kingdom (1981), Movimiento de las salamandras (1999), Ejercicios poéticos para cocinar (2012) y Exilios de medusa (2015), entre otros poemarios. Entre sus libros de crítica destacan Pablo de Rokha. Historia, utopía y producción literaria (1991), Antología crítica de la poesía cbilena: Tomo I (1996), Tomo II (2000), Tomo III (2002), Tomo IV (2006). Ha publicado varias antologías de poetas chilenos y más de 100 artículos de su especialidad. 


\section{Baldío}

"Nunca hubiera creído que la muerte se llevara a tantos" T. S. Eliot

Cuando despertó la pandemia todavía seguía ahí y recordó el cuento de Monterroso con algo de ironía con algo de pavor Durante los días anteriores tuvo varias pesadillas pero ninguna comparada con ésta Como toda persona letrada rememoró La peste de Camus El año de la peste de Dafoe y En las montañas de la locura de Lovecraft en la versión cinematográfica de Carpenter o los films directamente virales como Contagio de Soderbergh

o Pandemia nuestra antesala al infierno aunque por alguna razón le resonaba con mucha fuerza El bundimiento del Titanic de Hans Magnus Enzensberger esa metáfora de la modernidad ostentosa un barco monstruoso petrificado en el fondo de los mares

A su juicio la proliferación del virus expandiéndose por el mundillo de la especie humana dejando su marca afiebrada en tarjetas monedas mejillas administrando la vida y la muerte en los hospitales fuera de la biovigilancia y el control era solo un aviso de lo que vendría cuando la utopía de la comunidad inmune fantaseada por el nuevo sujeto del tecno patriarcado se convirtiera en el reality show más espectacular de las últimas décadas un desfile de fantasmas con mascarilla sin manos sin labios sin lengua sin rostro casi sin piel los nuevos intocables de una secta invisible que dejan mensajes en aparatos que nadie escucha sin cuerpo apenas una prótesis cibernética apenas una máscara entre otras máscaras un tapabocas que te obliga a callar con diferentes diseños para mantener la desigualdad social 
más allá de las imágenes cinematográficas

del zorro el jinete enmascarado o el enmascarado de plata

del dúo dinámico batman y robin

fuera del imperio fuera de la performance teatral

apenas un código una casilla en la nube una sombra

no se reúnen con nadie no tienen carne

su domicilio es amazon facebook instagram

una partícula de ser humano consumiéndose a sí mismo

en la soledad de un estado de excepción permanente

de cuerpos abducidos atemorizados encapsulados

¿Para siempre?

Cuando despertó pensando en el monstruo

pero también imaginando otro lugar otra ciudad

otro planeta donde fuéramos todos inmunes

sin cuerpos abyectos y extraños ni fronteras ni muros

se dio cuenta y por el resto de sus días

que el pensamiento no le servía para despertar

fuera de su casa del miedo (al) ajeno

para salir del encierro de su dormitorio

de la segunda dermis con sus guantes esterilizados

el temor a hacernos virales

si tocamos la puerta la basura la bolsa del pan

la saliva que sale de los labios amados

sonidos partículas vivas ventosas que se adhieren

a nuestros pulmones el temor

flotando de una garganta a otra sobrepasando

las barreras migratorias la vigilancia

digital y el flujo del capital

¿O es sólo la metáfora de otro texto mayor?

¿A quiénes dejaremos morir?

¿A los más pobres?

¿A los viejos con sus enfermedades primarias?

¿A las mujeres golpeadas maltratadas asesinadas?

$¿$ A los aborígenes exiliados de todas las tierras?

¿A los inmigrantes hacinados en barrios de la periferia?

¿A los marginales escondidos en sus carpas de cartón?

¿A los nuevos zombies sin rumbo vagando por las calles solitarias

de las ciudades del mundo? 
Despertó y se dio cuenta del espectáculo de la dramaturgia de la muerte los caídos ya no pueden ser felices o infelices ni siquiera tienen ataúd o ceremonia del adiós se quedan casi sin despedirse en medio de la calle en medio de las cloacas de los mercados semivacíos ateridos de frío o sudando por la canícula implacable bajo el hervor creciente de un sol moribundo multitudes de cuerpos frotándose unos con otros de carnes podridas y verduras disecadas exiliados de pueblos y casas sin hogar ni alimento espectadores sin ojos de su propia doble agonía probablemente sorprendidos por esta oscuridad por este desencuentro no querido ni anhelado por este pétalo negro de locura ya inscrito en los libros sagrados como un recuerdo de los dioses olvidados o un tic nervioso de la ciencia la mesurada y correcta tabla de salvación de la tragedia planetaria

Despertó y se dijo —en eso estamos ahoraconfinados controlados segmentados vigilados en fin "normalizados" en la micro república de una habitación en el umbral del afuera y el adentro en la prisión blanda del metro y medio de distancia en los tentáculos acomodaticios pero encubiertos del telecontrol custodiados desde el ciberespacio para que sigamos siendo los consumidores dóciles que soñaron que fuéramos tele alimentados todos

\section{Estamos}

en la batalla de Chile la batalla de Santiago la batalla del Universo "estamos en una guerra señores" y hay que ganarla aunque perdamos varios millones de "clientes" desbancados del mapa global invisibilizados en la televisión y los celulares donde los muertos como antes los desaparecidos no tienen consistencia 
para el espectáculo aséptico de todos los días somos un número una cantidad una ficha escamoteada de la vista de parientes y amigos a perpetuidad aunque él piensa no hay ninguna batalla que ganar o perder el virus es un dinosaurio una pesadilla un sueño una verdad que siempre estuvo allí y no tiene la culpa de nuestra insoportable levedad de existir de nuestra pretenciosa manera de mirarnos sin vernos la cara y de encerrarnos en la pesadez del miedo para vigilar prohibir castigar lucha donde Tanatos desplazó a Eros hasta nuevo aviso

Así es como la tierra se convirtió en una gran cárcel algunos nos encerramos en los rincones de casas o pernoctamos en otros lugares donde murallas y techos reducen nuestra mirada anclados a un presente interminable mientras una multitud de seres extraños sale de las alcantarillas y vaga por las calles sin rumbo como mutantes exiliados de las redes las pantallas los medios de comunicación como residuos en tránsito virus del virus también eliminados del porvenir que no está disponible que no les pertenece

¿Qué nos espera?

¿Cuándo será la próxima pandemia? ¿un planeta sin agua ni alimentos el baldío irreversible? ¿la radiación la guerra? ¿el frío y el calor recargado? ¿el fin de todas las predicciones el auto exterminio total?

¿Mutaremos?

Mientras tanto

el día venidero se nos escapa y desaparece en nuestra sociedad sin orificios en medio de nuestra disposición al aburrimiento (midiendo los pasos rumiando el desempleo acallando los gritos destemplados temiendo el sonido del timbre) Yo tú nosotros ellas en la jaula invisible monstruos todos 
saliendo de la pesadilla convertidos ahora en lo espeluznante "apretando nuestros ojos sin párpados esperando que llamen a la puerta" las ovejas negras abandonadas en la cuneta de la autopista de la globalización el tumor que se expande el tejido podrido que se filtra de la tierra una y otra vez invadiendo los campos y las ciudades para desandar

el camino de la especie

(12 de mayo de 2020) 


\section{MARIBEL MORA CURRIAO}

Es Magíster en Literatura de la Universidad de Chile, candidata a Doctora en Estudios Americanos de la Universidad de Santiago de Chile, Profesora de Castellano, Licenciada en Educación, orientadora educacional y vocacional, poeta e investigadora mapuche. Ha ejercido como profesora de enseñanza secundaria, de educación de adultos y en educación superior. Además de investigar sobre pueblos indígenas y sus expresiones literarias, se ha desempeñado como coordinadora en redes profesionales, en cargos de responsabilidad institucional, en la implementación de programas y en la realización de eventos nacionales e internacionales sobre pueblos indígenas de Latinoamérica. En la Universidad de Chile ha ejercido los cargos de encargada de Educación Inclusiva y actualmente es la directora de la Oficina de Equidad e Inclusión.

Poemas suyos se han publicado en diversas revistas y en antologías como 20 poetas mapuches contemporáneos (2003), Hilando en la memoria (2006) y La memoria iluminada: poesía mapuche contemporánea (2007). 


\section{Confinamientos}

Esta selección de poemas de distintos libros ha sido reunida especialmente para la Revista Anales de la Universidad de Chile a partir del concepto confinamiento, tan repetido en esta época de pandemia, y hecho vida más veces de las que quisiéramos en la historia humana.

\section{I}

\section{(Isla Martín García, 1884-1900)}

No éramos tan altas y perfectas como las romanas

No como estatuas de mármol.

No como diosas griegas.

Por eso nos llevaron a la Isla.

No para ver cómo rompían las olas contra los granitos o mirar las aves rapaces

engullendo pequeños peces.

No para dejarnos llevar pensándonos frágiles barcas hundiéndose en las aguas

abandonando el aire que no llegaría una tarde a los pulmones.

No tuvimos ese tiempo mientras tú como nosotras

pensabas en el hombre más bello del mundo mirando distraído

sin lograr mirarnos.

(Reporte oficial: 120 chinas prisioneras con sus criaturas sobrevivientes)

¿Supiste de esos ojos de mujeres, Alfonsina que también amaron hasta el dolor y la muerte? ¡Ay, Alfonsina! Seguro no supiste y no te juzgo, de esas manos que abrazaron esos cuerpos. De esas grandes mujeres donde posó el universo todo el amor y todo el dolor de los siglos. 
De esas grandes mujeres no supiste pero supiste de ese peso ancestral de no ser reina.

Grandes mujeres, gloriosas mujeres agrestes alzando sus alas como en ocultas selvas. $\mathrm{Pu}$ domo, pu pichidomo, pu papay, pu lamngen. Selvas de raíces trenzadas, mis abuelas.

Como tú, Alfonsina, dejaron de respirar un día, una noche después de las ráfagas, después del fuego después de la viruela

ahuyentando a los pájaros y los insectos de la pampa.

II

(Museo de La Plata, 1884-1888)

¿Y tú, Inakayal, te acuerdas del Museo?

El sitio perfecto entre los muros

La geometría indeleble en esas calles argentinas como la luna.

¿Conociste siquiera una muralla de la Ciudad de La Plata?

¿Pudiste mirar la perfección en esos parques?

¿O sólo las salas blancas del blanco museo allí donde pasaste tus días oprimido?

De un lado a otro te movías

buscando las ventanas

la salida

la escalera

que te liberara

del cautiverio infeliz e ignominioso

\section{(Museo de La Plata 1888-1994)}

Tus cabellos Inakayal por tantos ojos contemplados

cada día, cada año, cada década

de un siglo interminable como el oprobio. 
Tu cráneo,

$$
\begin{aligned}
& \text { tus húmeros } \\
& \text { tus fémures }
\end{aligned}
$$

observados hasta el infinito

detrás de las vidrieras

¡Y tan lejanos tus huesos

para tus deudos en la pampa!

\section{III \\ (Puerto Montt, septiembre de 2005)}

¿Y tu nombre Huenante?

Se perdió tu nombre, lamngen, en la ciudad sin muros.

Aquella ciudad puerto detuvo tus días.

En plena adolescencia

la democracia.

Y aquella ciudad puerto se llenó de fosas

Desde entonces sin nombres

en el iris de tu madre

tratando de adivinar en todos los flancos

el lugar exacto donde descansas...

todavía sin descanso.

IV

(Santiago de Chile, 2018)

kütran

Hambre

Soledad y frío

El machi sueña su rewe

(Santiago de Chile, 2020)

Kütran

Hambre

Pandemia

Soledad y frío

El machi sueña su rewe 
IVONNE COÑUECAR

Periodista y editora. Autora de los poemarios Chagas y Trasandina, y de Coyhaiqueer, novela que le valió el reconocimiento con el Premio Municipal de Literatura de Santiago 2019. Obtuvo la Beca Fundación Neruda (2007), la Beca de Creación Literaria del Fondo del Libro para Escritores Emergentes (2008 - 2009) y la Beca de Creación Literaria para Escritores Profesionales (2013). $\mathrm{Ha}$ participado en proyectos audiovisuales, dirige talleres literarios, presenciales y online. 


\section{Todo el dolor del mundo, y la biografía, caben en el recuerdo de un gato}

Chirimoyo iba a ser otro gatito en tránsito con un nombre que ya usamos. Colorín y blanco, como la chirimoya alegre. Con Nani fuimos de vacaciones a Coyhaique ese verano, nos habíamos ido a Rosario el año anterior, nuestro otro gatito, Laki, nos esperaba al cuidado de una amiga. Chiri nos enamoró y acortamos nuestro viaje, nos fuimos directo a Santiago, a Rosario y a casa.

Dicen que los gatitos vienen del cielo, cuando era chica me caían como estrellas fugaces y se me morían congelados o resfriados. No era costumbre llevarlos a una clínica veterinaria. Morían porque mi papá pensaba que nuestros medicamentos les podían hacer bien, o alguien prendía el motor del auto sin saber que alguno dormía ahí, o porque el perro corría más rápido. Vi muchos gatos morir, no podía hacer nada, ni decidir ni administrar cuidado. Crecí en el frío y en el hielo, y así como vi que mi ropa se quebraba al doblarla, también veía esos cuerpecitos tiesos. No despertaban, mi ropa tampoco podía volver a unirla.

Veía muertes y violencia por todas partes, en las fiestas familiares cuando carneaban un cordero y chorreaba la sangre que recogían antes de que se enfriara, o la gallina que mi nana mataba con un palo de coligüe que lo ponía atravesado en su pescuezo en el piso, y presionaba. Recuerdo el sonido y los ojos de la gallina. También salíamos a cazar y volvíamos con las aves a desplumarlas inmediatamente y a comerlas antes de que se pusieran hediondas, recuerdo el perol con cincuenta tordos que cazamos con mis hermanos en el campo del abuelo porque amenazaban la siembra. Siempre había un motivo para matar. A mí solo me dolían los gatos y perros, que pasaban como un desfile de muerte porque no sabía cuidarlos.

Cuando Chiri se agravó escuché a varias veterinarias, de Chile y Argentina, decir que la pandemia también los estaba afectando, por el estrés de compartir el espacio con personas durante la cuarentena. Ese no era nuestro tema porque trabajamos en casa, pero a Chiri le habían descubierto una nefropatía hacía dos años y en medio de la vorágine pandémica tuvimos que esperar para su control. Siempre se vio activo, juguetón, cuando caminaba parecía que flotaba sobre unas zapatillas de casa. Pero sus hematocritos se derrumbaron, una constante que veníamos viviendo desde su diagnóstico. Transfusión dijo la especialista, o se muere. Todos nuestros recursos tuvieron la prioridad, la posibilidad de que Chiri se nos fuera estaba ahí, por primera vez, el peor escenario del que nos hablaron estaba volviéndose escenografía. Dejé que se fuera al carajo el malabarismo económico de cuarentena y caos mundial. Pensé en todos mis muertos, como si hubiera preparación para la muerte, pero la muerte es siempre actual y siempre golpea. Y la enfermedad simplemente llega y es incierta. 
Fernández amplía la cuarentena, algo en mí agradece, algo en mí se pregunta por el tratamiento de Chiri. Desde hace días practicamos no querer saber de Chile, la saturación del show infantil del gobierno de Piñera y su guerra, agobia. Evitamos pronunciar el desastre chileno, ahora vivimos aquí, decimos. Esta pandemia ha vuelto la cordillera al revés y es una grieta gigante que nos va separando, pero no me puedo despedir de Chile, habito ambos países. Me paseo dos o tres veces por la noche, digo - sin creerlo- que todo estará bien, salgo a la terraza y veo la calle vacía, algo me vacía y recuerdo que esto es así. Desde que comenzó he gestionado todo tipo de demonios, monstruos, paranoias, incertidumbres, insomnios, desidia; han aparecido apocalipsis, bombas atómicas, terremotos alucinantes, invasiones alienígenas, y esos dos pequeños me acompañan en estos paseos de madrugada.

Hubo que coordinar dos ecografías, un doppler, una muestra de sangre. Al parecer es congénito, no sé cómo está vivo con estos riñones deformes dijo la ecógrafa, si fuera humano estaría primero en la lista para trasplante. No es humano. No hay trasplante. Me pregunto si estaría de acuerdo con un trasplante. Traslados en taxis. Consultas veterinarias. Decimos qué bien que estamos acá, en Chile no podríamos pagar esto. El dinero siempre escasea. Chiri se estresa con los viajes, lo vemos sufrir. La tarde de la transfusión mordió a una vet, calmé su estrés poniendo mi mano lentamente sobre su pechito, ven gatito, ven hijo, tranquilo, le decía, y en la sala se veían los pelos y sangre por todos lados. Tuvimos que quedarnos con él y mantenerlo quieto. Si lo sedaban podía morirse por lo débil que estaba. La transfusión lo dejó ido, pasaron dos días antes de tenerlo de vuelta, antes de que volviera a jugar, aunque su rostro quedó triste. Estaba vivo, pero no dejamos de preguntarnos a qué costo. Decidimos que no habría más transfusiones. Luego hubo que ir varias veces a la vet para inyectarle vitaminas. Cuando veía que nos poníamos los zapatos se escondía. Una mañana jugando con Laki le dio un síncope, sus pupilas dilatadas lo mostraban aterrado a la vez que no podía moverse. Lo llevamos de inmediato a la vet. Un nuevo examen de sangre, hematocritos aún más bajos, un gatito pálido y helado. Dijimos no más, lo llevamos a casa y se acabaron los tratamientos.

Fueron dos semanas en las que perdimos la noción del tiempo, pasamos a turnarnos para estar las veinticuatro horas con Chiri, lo vimos debilitarse poco a poco. No quería ir a la pieza, así que abrimos el sofá cama y el living se convirtió en una estación de enfermería. Los últimos días ya no pudo pararse, a veces tenía impulsos y lo celebrábamos. O hacíamos sonar el plato donde le dábamos atún y asomaba su cabecita, con bastante cansancio. Un día tuvo un impulso y tambaleándose llegó a la ventana, quería ir a la terraza. Comenzó a comer piedras de su baño, tuvimos que evitarlo y se enojaba, miraba el agua sin beber, teníamos que animarlo para que se hidratara. Tuvimos esperanza en la homeopatía, fue lo 
último a lo que nos aferramos, pero nada salvaría a Chiri. Hice comidas especiales, fui a una carnicería del antiguo barrio porque estaba segura de que esa carne sí la comería, compré su alimento especial en tres mascoterías para asegurarme de que no le faltara, tenía que llevarme todo porque así evitaría que muriera, anoté en mi calendario las dosis de ferroglobin por meses como si esa programación pudiera combatir con la muerte. Dejamos de dormir, no queríamos perdernos nada, todo se fue aplazando, ese tiempo tendría que ser de los cuatro. Las noticias quedaron lejos, leía datos a diario, datos, no quería reflexionar ni opinar. Toda esa energía la necesitaba para Chiri.

Me llegaron fotos y videos de la nieve que cayó en Coyhaique, las mandan amigas que recuerdan esa antigua petición que les hice cuando me vine, porque siempre echo de menos la nieve de la Patagonia. Este año el tiempo simplemente pasó y fue para Chiri. Nos vemos cansadas, pero no destruidas. Era tan probable que a Chiri le diera otro síncope. Al otro lado Chile arde, los muertos aumentan, el virus también está cerca de nuestras familias. Mi cuñado es kinesiólogo y estuvo con un médico que resultó positivo y activó las alarmas familiares. El virus, aunque no prendiera la tv ni revisara redes sociales, estaba ahí. El sábado, un día gris y de lluvia, Chiri dejó de comer. No recibía ni atún ni carne. Laki también veía cómo se debilitaba, y bajó su ritmo, a veces lo olía, a veces lo lavaba, pero ya no lo buscaba para jugar. Renunció Mañalich le cuento medio en voz baja a Nani, un alivio nos recorre con desgano.

La última noche le dimos de beber un complemento alimenticio, lo saboreaba pese a que le costaba tragar, sabíamos que le molestaba la acidez. Le quisimos dar un poco más y se levantó e hizo unos movimientos con las patas traseras. Débora, nuestra amiga vet que nos ayudaba desde Coyhaique, dijo que tenía la uremia alta. Nos dijo descansen, duerman, mañana intentamos de nuevo. El domingo salió el sol potente, enorme y ese olor a mar del río Paraná nos revitalizaba. Chiri lanzó un maullido que por un momento nos hizo imaginar que se levantaría y sería el de siempre, el que jugaba solito en la terraza con las hojas que caían del jardín de la vecina del décimo, el que miraba la calle y los pájaros desde su rascador. Con Nani tuvimos que hablar de la posibilidad de eutanasia, ambas estuvimos de acuerdo en que no, le habíamos dicho a Chiri que no más jeringas ni estrés, sería una traición traer a alguien para que lo durmiera. Quise sacar a Chiri a la terraza a ver el sol, como hacíamos esta cuarentena por la vitamina D. Pero lo dejé dormir cuidando sus latidos, contando su respiración, hablándole de cuando lo encontró Nani y de cuando conoció a Laki. Vomitó algo espumoso y amarillento. Débora dijo que había daño hepático, que no hay nada más por hacer. Me sentí derrotada, solo había que esperar. Lo pusimos en medio del sofá y nos sentamos a su lado. Pusimos una playlist de chillhop que usamos para estudiar y que los hacían dormir. 
Murió en nuestros brazos. Le dije que con Nani le habíamos construido un lugar infinito e imaginario que lo estaba esperando y donde lo visitaríamos. Se lo dije al oído mientras exhalaba como un niño resfriado. Le dije ¡Salta! ¡Salta hijo! ¡Salta! Como si hubiera un valle de pasto donde no tendría más miedo ni malestar nuestro principito, ojitos de miel, chiripatotas, pelito de trigo, nuestro tigrito, nuestro niño, el más pequeñito de todos. Nani sostenía su cuerpo, yo su cabecita. Laki miraba desde la mesa. Murió en un atardecer soleado, de luz naranja, a las seis y veinticinco de la tarde. El amanecer y el atardecer eran sus horas favoritas porque salían a revolotear más pajaritos. El silencio y la calma también nos alivió. Comencé a buscar un lugar donde enterrarlo, había algo fuera de Rosario, le envié un mensaje a Elisa por si sabía de otro lugar. Dijo que lo dejemos en su patio, que nos pasa a buscar a la mañana. Lo más temprano dije, a las siete de la mañana nos propuso. Llamé a Raúl, con quien tenía clases al día siguiente, también me iba a llamar me dijo, murió mi cuñado por covid hace un rato. Estaba destrozado. Ambos nos escuchábamos llorosos, hablando con esa lentitud para no explotar del llanto. Cortamos. Ese día Chile superaba los doscientos mil casos y las dudas por la cantidad de muertos subía. En Rosario no se registraban casos desde hacía dos semanas y habían autorizado algunas actividades.

Elisa fue la primera amiga que veíamos desde marzo. Llegó en su auto, nos saludamos sin tocarnos, las tres con mascarilla. Tuvo el detalle de pasar por nuestro antiguo departamento, al que llegó Chiri desde la Patagonia. Su patio es un lugar hermoso lleno de flores y árboles. Hicimos el hoyo, ella nos dejó solas un momento y trajo flores. De regreso nos abrazó. No había sentido ningún cuerpo excepto el de Nani. Ya no es igual un abrazo, se piensa y se desconfía, el daño de la pandemia está en todos lados. En casa Laki lo busca. Los veo correr y esconderse. Esa tarde estuvimos con las persianas abajo. A las cinco de la tarde asistí al primer velorio online para acompañar a mi amigo. Todo lo que veíamos como pesadilla en Europa está sucediendo. Las víctimas de la necropolítica de Piñera tienen nombre. Era tanta cordillera la tristeza. Chile corrige la cantidad de muertos, son más de siete mil. En realidad, sí hay momentos en que se acaban las palabras, así como los gatos que veía morir de niña y que parecieran no importarle a nadie, veo una industria de la muerte del gobierno que quiere arrebatarles hasta los nombres a los muertos. 